\title{
The Sustainable Debts of Philip II: A Reconstruction of Castile's Fiscal Position, 1566-1596
}

\author{
MAURICIO DRELICHMAN AND HANS-JOACHIM VoTH
}

\begin{abstract}
The defaults of Philip II have attained mythical status as the origin of sovereign debt crises. We reassess the fiscal position of Habsburg Castile, deriving comprehensive estimates of revenue, debt, and expenditure from new archival data. The king's debts were sustainable. Primary surpluses were large and rising. Debt-to-revenue ratios remained broadly unchanged during Philip's reign. Castilian finances in the sixteenth century compare favorably with those of other early modern fiscal states at the height of their imperial ambitions, including Britain. The defaults of Philip II therefore reflected short-term liquidity crises, and were not a sign of unsustainable debts.
\end{abstract}

Spain under the Habsburgs ruled an empire on which the sun never

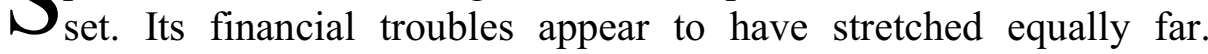
Castile-Habsburg Spain's dominant kingdom—was the first "serial defaulter" in history. ${ }^{1}$ Philip II failed to honor his debts four times, in $1557,1560,1575$, and 1596. Historians have emphasized the hopelessness of Castile's fiscal position. ${ }^{2}$ Fernand Braudel famously

The Journal of Economic History, Vol. 70, No. 4 (December 2010). (C) The Economic History Association. All rights reserved. ISSN 0022-0507.

Mauricio Drelichman is Assistant Professor, Department of Economics, The University of British Columbia, 997-1873 East Mall, Vancouver, BC V6T 1Z1 Canada; and CIFAR. E-mail: drelichm@interchange.ubc.ca. Hans-Joachim Voth is ICREA Research Professor, Department of Economics, Universitat Pompeu Fabra, Ramon Trias Fargas 25-27, 08005 Barcelona; and CREI.

For helpful comments, we thank Daron Acemoglu, George Akerlof, Carlos Alvarez Nogal, Fernando Broner, Albert Carreras, Marc Flandreau, Caroline Fohlin, Regina Grafe, Avner Greif, Phil Hoffman, Viktoria Hnatkovska, Tim Leunig, Alberto Martín, Paolo Mauro, David Mitch, Kris Mitchener, Joel Mokyr, Lyndon Moore, Roger Myerson, Sevket Pamuk, Richard Portes, Leandro Prados de la Escosura, Angela Redish, Kevin O'Rourke, Nathan Sussman, Alan M. Taylor, Francois Velde, Jaume Ventura, and Eugene White. Seminar audiences at American University, ECB/Bundesbank Workshop, Harvard, Sciences Po, Hebrew University, UBC, UPF, UC Irvine, LSE, HEI Geneva, NYU-Stern, Rutgers, and Stanford as well as the EHA meetings in Austin, the CREI/CEPR Conference on "Crises: Past, Policy, and Theory," CIFAR, NBER, CEPR-ESSIM, the BETA Workshop, and the Utrecht Workshop on Financial History offered advice and constructive criticism. Marcos Agurto, Hans-Christian Boy, Diego Pereira, Germán Pupato, Javier Torres, Cristian Troncoso-Valverde, and Anthony Wray provided outstanding research assistance. Financial support from the Spanish Ministry of Science and Innovation, the Barcelona GSE Research Network, the Generalitat de Catalunya, SSHRCC, UBC Hampton Fund, and TARGET/INE is gratefully acknowledged.

${ }^{1}$ Reinhart, Rogoff, and Savastano, "Debt."

${ }^{2}$ According to Thompson, "Castile: Polity," Castile suffered from "an unbridgeable gap between unavoidable expenditure and disposable income." See also Lovett, "General Settlement." 
argued that only the indulgence of irrational bankers allowed Castile to incur towering debts at a time when its fiscal position was deteriorating. ${ }^{3}$ Fighting a series of expensive wars in a bid for European hegemony, public finances were heavily strained. Spain eventually came to hold the all-time record for the number of government bankruptcies, having failed to meet its obligations 13 times between 1500 and 1900 . There is a widespread belief that military expenditures eventually overburdened the economy, resulting in "imperial overstretch."

While Spain's numerous defaults between 1556 and 1900 are widely cited in the literature on sovereign debt crises, we know relatively little about Castile's fiscal position from a macroeconomic perspective. Evidence on tax revenues, expenditure, and debt is fragmentary. Philip II himself-like most early modern rulershad very limited information about the state of his finances. The decentralized nature of early modern states, combined with rudimentary information collection, hinders attempts at reconstruction. Assessing the overall fiscal position of Habsburg Castile, therefore, requires the painstaking collection of data from scattered sources, and the use of careful assumptions regarding the nature of missing data.

In this article, we reconstruct the earliest set of annual fiscal accounts for any sovereign state in history. We provide estimates of overall debt, debt servicing, revenue, and expenditure in Philip II's Castile for the period 1566 to 1596 . Our starting point is a new data series of the Crown's short-term debts, compiled from archival documents held in the Archive of Simancas. When combined with existing data, this series serves as the linchpin of our reconstruction of the year-to-year movements in Philip II's fiscal position. We derive yearly estimates of the budget deficit, the primary surplus, short-term borrowing, and the stock of long-term debt. ${ }^{5}$

Our data can be used to evaluate debt sustainability. Philip's debts did not exceed future discounted primary surpluses. Rising debt was met with rising revenue. Contrary to received wisdom, Philip II's debts were sustainable throughout his reign. Castile's fiscal position only weakened after the defeat of the "Invincible Armada," and this deterioration was mild. Far from being undermined by reckless spending and weak fiscal institutions, Castile's finances mainly suffered large, temporary shocks as a result of military events.

\footnotetext{
${ }^{3}$ Braudel, Mediterranean.

${ }^{4}$ Alvarez Nogal and Prados de la Escosura, "Decline," document Spain's poor economic performance over the long run. See also Kennedy, Rise.

${ }^{5}$ Space constraints do not allow us to reproduce the reconstructed series here. An online version of the article, available on the authors' web sites, reports the full series and provides complete details on the methodology employed.
} 
To put these findings in context, we compare Castile's finances with those of other early modern European powers, such as France, Holland, and Britain. Castile ran primary surpluses larger than those in eighteenth-century Britain, which has long been regarded as a paragon of fiscal virtue. ${ }^{6}$ This is all the more remarkable since Castile found itself almost continuously at war. Our findings suggest that earlier assessments of Philip's finances have been too pessimistic. The overall health of Castile's fiscal position, and the Crown's ability to raise taxes and non-tax revenue, made continued borrowing possible. ${ }^{7}$ Our finding also implies that the "defaults" reflected temporary liquidity shortfalls, and were not a sign of insolvency. ${ }^{8}$

Our research is related to other work on early modern European state finances. Carmen Reinhart, Kenneth Rogoff, and Miguel Savastano reconstruct the long-run history of debt and defaults since 1500. Richard Bonney's European State Finance Database offers a comprehensive overview of existing data. Eugene White pioneered the use of primary surpluses as an analytic device in the context of early modern state borrowing. Other important contributions include the works of Philip T. Hoffman and Kathryn Norberg, and of Mark Ormrod, Richard Bonney, and Margaret Bonney. John Brewer examined the rise of the tax state in the United Kingdom in response to the fiscal exigencies brought on by war. François Velde has compiled detailed data on early-eighteenth-century France. ${ }^{9}$ In combination, these works offer insights into the "sinews of power" of almost every nascent European national state. Castile has also attracted scholarly attention. ${ }^{10}$ Modesto Ulloa provides time series on revenue sources during Philip's reign. Henri Lapeyre, Felipe Ruiz Martín, Ramón Carande, Miguel Artola, and Pilar Toboso Sánchez supply fragmentary evidence on short- and long-term debt. I. A. A. Thompson compiled snapshot data on expenditure for selected years. ${ }^{11}$

\footnotetext{
${ }^{6}$ See Ferguson, Cash; and Brewer, Sinews.

${ }^{7}$ The reasons for the Crown's willingness to repay are explored in Drelichman and Voth, "Lending to Borrower."

${ }^{8}$ In this sense, Philip's defaults would have been excusable in the sense of Grossman and Van Huyck, "Sovereign Debt."

${ }^{9}$ Reinhart, Rogoff, and Savastano, "Debt"; Bonney, European State and Rise; White, "Was There a Solution?"; Hoffman and Norberg, Fiscal Crises; Ormrod, Bonney, and Bonney, Crises; Brewer, Sinews; and Velde, "John Law's."

${ }^{10}$ For the sixteenth century, the classic works are Ruiz Martín, "Expediente" and "Finanzas"; Ulloa, Hacienda; and Artola, Hacienda. More recently, Bilbao, "Ensayo"; Thompson, "Castile: Polity"; Gelabert, "Castile"; Marcos Martín, España; Tortella and Comín, "Fiscal and Monetary Institutions"; Yun Casalilla, "Siglo" and Marte; and Alvarez Nogal and Prados de la Escosura, "Decline," have contributed much to our understanding of Spanish economic and fiscal history.

${ }^{11}$ Ulloa, Hacienda; Lapeyre, Simón Ruiz; Ruiz Martín, "Finanzas"; Carande, Carlos V; Artola, Hacienda; Toboso Sánchez, Deuda; and Thompson, War and Society.
} 


\section{HISTORICAL BACKGROUND: THE WARS AND FINANCES OF PHILIP II}

From 1556 to 1598 Philip II ruled the entire territory of modernday Spain; Northern Catalonia (eventually ceded to France); large parts of the Low Countries; Naples, Sicily, and Milan; and the New World from Buenos Aires to Lower California (with the exception of Brazil). In 1571 he acquired the Philippines and from 1580 he also ruled Portugal and its merchant empire. Spain itself consisted of several kingdoms. Castile was dominant, accounting for as much as 83 percent of the population. ${ }^{12}$ In 1479 the marriage of the Catholic kings joined the Crowns of Castile and Aragon. ${ }^{13}$ Castile was given exclusive control over territory conquered in the future; the conquest of Spanish America, therefore, strengthened her position.

Both Castile and Aragon had representative assemblies, the Cortes. In the sixteenth century, the Cortes of Castile consisted of representatives from 18 major cities. These had to approve direct taxes (servicios), sales taxes (alcabalas), as well as a few additional income streams. Between 1555 and 1596 taxes subject to approval by the Cortes generated 43 percent of Crown revenue. ${ }^{14}$ Taxes were classified by the Cortes as either "ordinary" or "extraordinary." Since the Crown could only sell long-dated bonds backed by ordinary tax revenue, the Cortes effectively set a limit on issuance. ${ }^{15}$ Tax payments were often fixed in nominal terms. Therefore, the price revolution of the sixteenth century created a need to increase these taxes. Requests to do so were not approved easily. The Cortes regularly negotiated the size of the change, attached conditions to it, and prolonged debate indefinitely if the king offered insufficient concessions. ${ }^{16}$

Philip II twice faced strong opposition by the Cortes. In 1574 the king requested a tripling of the sales taxes. The Cortes stalled. A compromise emerged in 1575 , too late to prevent a default on shortterm debt. Sales taxes were doubled, with an additional onetime levy. The extra revenue helped the Crown settle with its bankers. The second standoff between the king and the Cortes came in 1590, in the aftermath

\footnotetext{
${ }^{12}$ Nadal i Oller, Población.

${ }^{13}$ The union of the crowns of Aragon and Castile was not a full political merger-taxes, laws, and constitutional rules remained largely unchanged.

${ }^{14}$ The king could collect ecclesiastical revenue without the Cortes' approval. Mining revenue was also part of the royal prerogative (Ulloa, Hacienda, pp. 83-87). The section on data discusses the composition of revenue in detail.

${ }^{15}$ Torres López and Pérez-Prendes, Juros.

${ }^{16}$ The literature on the Cortes is vast. Important treatments include Carretero Zamora, Cortes; Jago, "Habsburg Absolutism" and "Philip II"; Thompson, War and Society, Crown, and "Castile: Absolutism"; Fortea, Cortes; and the proceedings of the Congreso Científico sobre la Historia de las Cortes de Castilla y León (Las Cortes).
} 
of the Armada. The king requested new excise taxes from the Cortesthe millones. In response, the Cortes attached conditions limiting the king's power to impose levies on cities. They also gained, for the first time, limited control over royal expenditure. In fiscal terms, royal power in Castile was thus far from absolute. The Cortes had little control over expenditure, but it could influence taxation to a large extent. Without them designating revenue as "ordinary," no issuance of long-term debt was possible. The Crown's relationship with the Cortes was therefore crucial for Castile's fiscal position.

From the 1540s Spain received large inflows of silver from the New World. The Crown taxed all remittances at a flat rate of 20 percent. Silver revenue was volatile, and grew quickly. It eventually became an important source of funds; by 1596 one in four ducats of Crown revenue came from silver taxes. ${ }^{17}$ These were beyond the Cortes' control. They could also not be used to back long-dated bonds. Instead, silver was used to fund short-term borrowing. The timing of silver inflows was a key factor in three of the four defaults of Philip's reign-Figure 1 shows sizable dips in remittances in the years preceding the 1560,1575 , and 1596 bankruptcies.

Philip was at war for almost all of his reign. Some military endeavors were great successes; others ended in spectacular failure. Spanish territories and Spain's allies paid to a varying extent for these military campaigns, but the Castilian treasury was by far the largest contributor. In Flanders, disagreements over taxation combined with religious issues to produce a full-scale revolt after 1567. Philip's military governor, the Duke of Alba, persecuted Protestants with an iron fist, fanning the flames of rebellion. Flemish and Dutch revenue fell far short of spending in the Low Countries and the Army of Flanders became a major expenditure item in the Castilian budget. At the same time, Philip and his allies fought the Ottomans in the Mediterranean, defeating them at Lepanto in 1571. Expenses in Flanders and in the Mediterranean exceeded available revenue. When the Cortes initially refused new taxes, Philip stopped servicing his short-term debts in $1575 .{ }^{18}$ In the following year, after the death of the governor general, Spanish troops mutinied and sacked the loyal city of Antwerp. The Flemish and Dutch provinces united against the

\footnotetext{
${ }^{17}$ American silver remittances are examined in Hamilton, American Treasure; and Morineau, Incroyables Gazettes. Ulloa, Hacienda, pp. 687-714, provides extensive data on New World revenues. For the role of silver in the interaction between the Crown and the Cortes, see Drelichman and Voth, "Institutions."

${ }^{18}$ This discussion is based on Parker, "Spain," Dutch Revolt, Spain, Grand Strategy, and Army.
} 


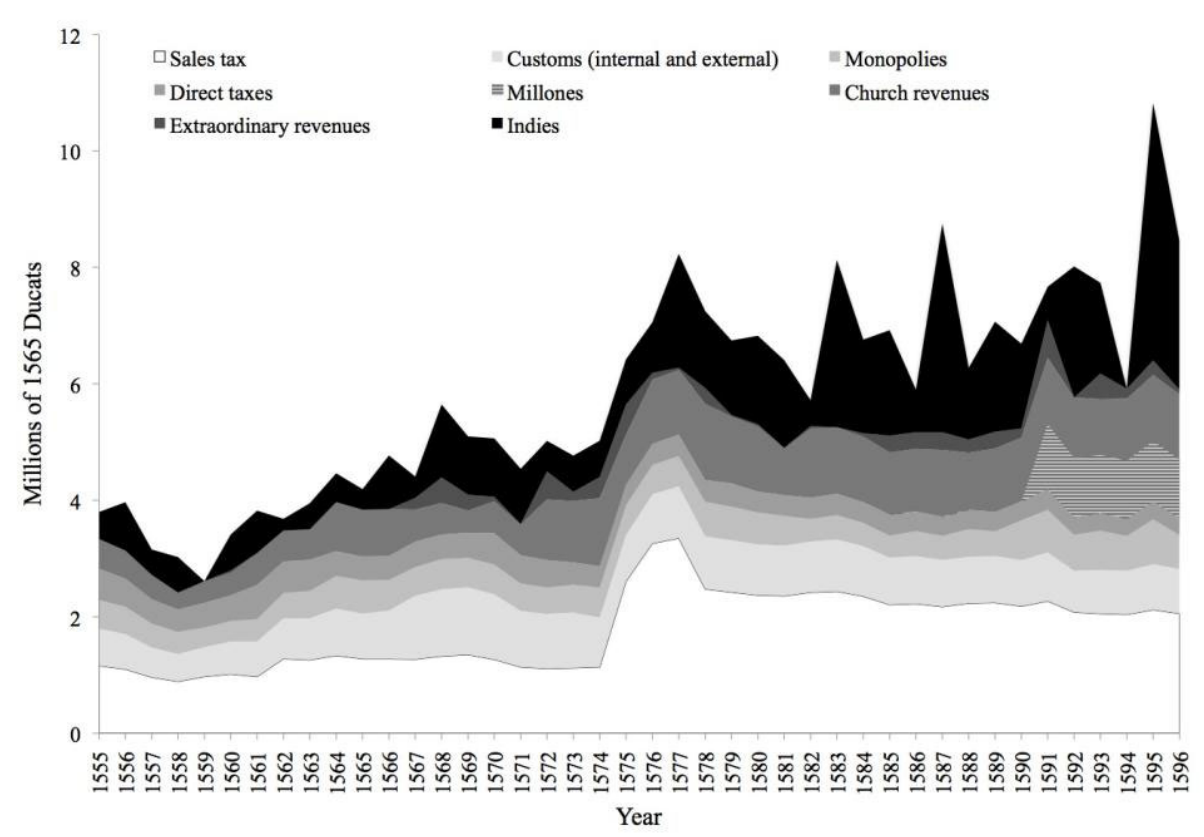

FIGURE 1

CROWN REVENUES, 1555-1596

Sources: Ulloa, Hacienda; Thompson, War and Society, p. 288; and authors' calculations.

mutineers, and drove Spanish troops out of large parts of the Low Countries. By 1585 Spanish forces recaptured Antwerp and other parts of the Netherlands, but the Army of Flanders never conquered all of Holland and Zeeland. This was widely blamed on English support for the rebels, leading Philip II and his advisors to plan an invasion of England with the "Invincible Armada." Building it cost two years" worth of revenue. ${ }^{19}$ When the fleet was destroyed, Spain had to rebuild its naval forces, strengthen her fortifications, and repel English and French attacks. The additional cost placed a heavy burden on royal finances. Despite a new tax (the millones), the king defaulted again in 1596.

Debt was issued in two forms, asientos and juros. Asientos were short-term debt contracts negotiated between the Crown and its bankers. Many of them involved transfers of funds abroad. During Philip's reign, they usually included a license to export bullion from Castile, as well as protection against a debasement of the currency. The king was often in arrears on his asientos. Juros were long-term bonds issued against a particular revenue stream, such as the sales taxes of Seville. Because

\footnotetext{
${ }^{19}$ Our calculations, based on Parker, Spain and Army.
} 
they were backed by specific tax streams, juros were safer investments than asientos; Philip II never defaulted on them.

Philip stopped servicing short-term loans one year after his accession. He did so again in 1575 and 1596. The first rescheduling unfolded in two stages, in 1557 and 1560. The settlement involved the Fugger banking family taking control of Crown land and monopolies, and was not fully negotiated until 1566, when lending resumed in earnest. Many funds were provided by Genoese bankers, who introduced the practice of collateralizing asientos with juros. As fighting in the Netherlands and in the Mediterranean escalated, so did borrowing. When the Cortes refused new taxes, the king once again defaulted on asientos. The total outstanding amount was 14.6 million ducats, or two years' worth of revenue. Five and a half million ducats had been collateralized through standard juros, while 4.3 million were backed by bonds guaranteed by the Casa de Contratación. ${ }^{20}$

The crisis of 1575 is well-documented. ${ }^{21}$ Two years of negotiations with the bankers produced a settlement (medio general), converting all short-term loans to low interest perpetuities. On average, the king repaid 62 percent of his debts. The bankers extended fresh credit amounting to five million ducats. Lending continued briskly until 1596. In that year, Philip suspended payments for the fourth time. The new settlement was mild compared to the 1575 default. The medio general of 1597 rescheduled 7 million ducats, about 65 percent of yearly revenue. Two-thirds of outstanding debt was converted to 5 percent juros, and the rest was repaid in full through a juros swap. The king repaid 80 percent of outstanding debt and accrued interest.

\section{DATA}

Figure 1 shows the evolution of the Crown's revenues by type between 1555 and 1596 in constant 1565 ducats. Data for individual revenue streams between 1555 and 1596 were collected by Ulloa and Thompson. For years with missing observations, we assume that revenues were equal to the lower of the two closest years with available data. We also use information on the frequency of tax collection. ${ }^{22}$

\footnotetext{
${ }^{20}$ Income of the Casa de la Contratación was a royal prerogative. The juros issued against these revenues are one notable exception to rule that long-term debt had to be backed by Cortes-approved ordinary revenue (Ruíz Martín, "Expediente").

${ }^{21}$ For more details on the suspension and settlement, see Lovett, "Castilian Bankruptcy" and "General Settlement"; as well as the online version of this article.

${ }^{22}$ This procedure and Ulloa's methodology yield a lower bound of actual revenue. Most revenue remained constant for long periods. Data for Indies revenue, the most volatile series, are available for every year. The online version of the article provides the complete data set used to construct Figure 1.
} 


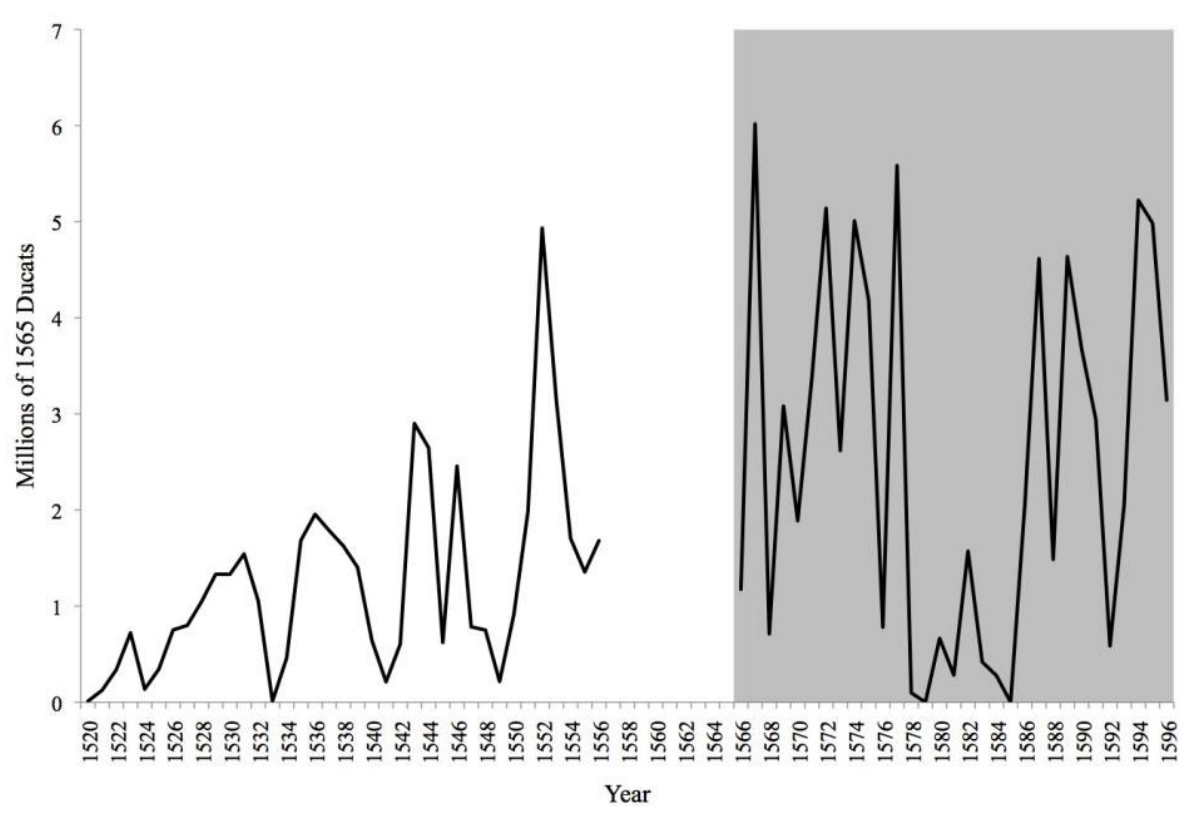

FIGURE 2

GROSS VALUE OF NEW ASIENTO ISSUES

Sources: Artola, Hacienda, pp. 86-87; and Archivo General de Simancas, "Contadurías Generales," Legajos 84-92.

Our new series broadly agrees with existing estimates for individual years. ${ }^{23}$ With the exception of silver remittances (the topmost category in the chart), revenues were largely stable because of tax farming. Tax farmers or city councils agreed to fixed yearly payments and became the residual claimants. Sales taxes were doubled in 1575 and the millones excises were introduced in 1591. Almost the entire volatility of the series is driven by silver revenue. The yield of the Potosí mines fluctuated from year to year, and these swings were accentuated by difficulties in shipping silver across the Atlantic.

In each bankruptcy, short-term loans were converted into long-term debt. The Crown would issue fresh juros, secured against new taxes voted by the Cortes. This also implies that after each general settlement (medio general) that ended the bankruptcies, the Crown was free of short-term obligations. We will exploit this fact to reconstruct the total debt stock.

Figure 2 shows the real gross value of new asientos contracted between 1520 and 1596. The new data constructed from the original loan contracts in the Simancas Archive begins in $1566 .{ }^{24}$ The $1520-1556$ series

${ }^{23}$ For a more detailed comparison, see the online version of this article.

${ }^{24}$ Archivo General de Simancas, "Contadurías Generales,” Legajos 84-92. This series begins 


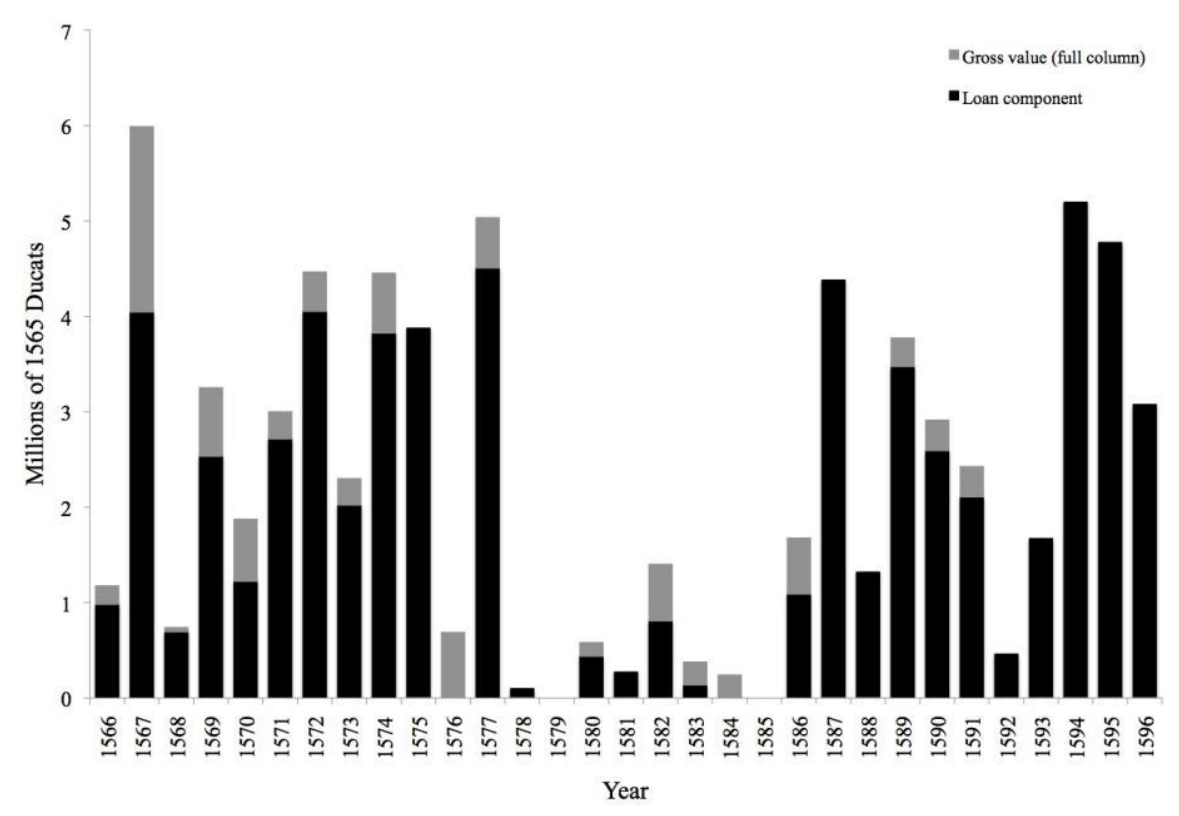

FIGURE 3

LOAN COMPONENT OF NEW ASIENTO ISSUES

Source: Archivo General de Simancas, "Contadurías Generales," Legajos 84-92.

was assembled by Carande. Previous data on Philip II's asientos were problematic. Ulloa's series suffered from double counting. ${ }^{25}$ In addition, both Carande's and Ulloa's estimates were based on the gross amounts mentioned on the front page of the asiento documents, part of which involved transfers and exchange operations that did not increase debt.

In the absence of reliable data on short-term borrowing, it was impossible to reconstruct total debt and annual borrowing accurately. Our new series is free of double counting, and we distinguish between actual borrowing and other uses of funds. This required analyzing the actual clauses in each contract. We conducted the first such systematic analysis for all 416 asientos underwritten between 1566 and 1596. Figure 3 shows both gross values and loan components. Actual loans averaged 80 percent of gross values mentioned on the first page of asientos. Their earlier use exaggerated short-term borrowing, especially before 1586 .

in 1566, while Carande's study ends in 1556. The 10-year gap in the archive encompasses Philip's first two bankruptcies. These may have had repercussions for spending, and for dealings with the Cortes. The online version reports the nominal data used to construct Figures 2 and 3 .

${ }^{25}$ This resulted from the fact that military commanders would take out asientos with financiers in the field, and send the documents to Madrid. They would then be reissued, and often consolidated with other debt. 
To reconstruct a full set of fiscal accounts, we need the cost of servicing debts. Asientos were convenient as a short-term borrowing device; they allowed the Crown to obtain money quickly and transfer it to virtually any point in its European dominions. They were also expensive. Their median gross rate of return was 14 percent, and many contracts cost more than 20 percent. This included compensation for currency conversions, overseas deliveries, transportation costs, and the risk of late payment and subsequent renegotiation. Many asientos used convoluted contractual forms. Much of the return resulted from exchange transactions at favorable rates, advance payments by the Crown without interest, and swaps of financial instruments. Further complicating matters, scheduled repayments seldom specified whether they constituted interest or capital installments. Debt service is therefore not observable directly. We use an indirect estimation methodology instead.

First, we transcribed every clause in each of the 416 asientos contracted between 1566 and 1596 . We thus derived the monthly cash flow agreed in the contracts. From the overall set of cash flows in each contract, we calculated a modified internal rate of return for the asiento. ${ }^{26} \mathrm{We}$ then estimated the total interest for each contract by multiplying its loan component by the rate of return. We also spread the total service of each asiento - interest and principal payments - uniformly over the life of the contract. This is in line with what the few asientos separating interest and principal repayment specify. ${ }^{27}$ Annual debt service of the Crown is then the sum of these payments for all asiento contracts in force in any one year. Since the default of September 1575 stopped payments on all asientos, we use a value of zero for 1576 and 1577 . The settlement of 1577 converted all outstanding asientos into juros; short-term lending restarted from scratch in early $1578 .^{28}$

Juros were normally perpetuities, but lifetime bonds were also issued. Many were held by the Castilian nobility and bourgeoisie. With a royal license (available for a fee), juros could be traded in a secondary market. The value of a juro reflected the reliability of a particular revenue stream. Interest rates were typically around 7 percent. Table 1 shows the scant

\footnotetext{
${ }^{26}$ See Drelichman and Voth, "Serial Defaults," for further details.

${ }^{27}$ For a prominent example, see the 5 million ducat loan arranged after the 1575 bankruptcy. Asiento y Medio General de la Hacienda. Archivo General de Simancas, "Consejo y Juntas de Hacienda," Libro 42. Modifying this assumption to a pure front-loading of interest has a negligible impact on the rest of our estimates.

${ }^{28}$ We report the series of asientos, their loan components, and the estimated debt servicing in the online version of this article.
} 
TABLE 1

JUROS AND THEIR SERVICE

(in millions of ducats)

Sources: Debt estimates for 1560,1565 , and 1598 are from Artola, Hacienda, pp. 88-89; the figure for 1575 is from Carlos Morales, Felipe II, pp. 142-43. Service estimates are from Ruíz Martín, "Expediente," p. 71; and Ulloa, Hacienda, pp. 828-29.

available data on juros. ${ }^{29}$ Since these data are not sufficient to compile annual estimates of long-term debt and servicing costs, we will calculate them indirectly later.

No systematic data on Castile's expenditure during the sixteenth century exist. Civil administration, domestic law enforcement, and the maintenance of the royal household constituted a small part of Castile's budget - either because the expense itself was small, or because it was borne at the local level. The single largest expenditure item was military outlays. We use advances in Spanish military history over the last decade to compile comprehensive estimates of military expenditures. In the next section, we derive nonmilitary expenditure using an accounting identity.

Figure 4 presents our estimates of military expenditure between 1565 and $1596 .{ }^{30}$ Where the cost of an individual campaign differs across sources, we chose the estimate supported by better documentation. ${ }^{31}$ In the early 1570s the War of the Holy League and the growing intensity

\footnotetext{
${ }^{29}$ The archives do not permit a full reconstruction of the stock of juros. Existing estimates are derived from official inquiries. Most of them were commissioned at the time of the defaults. A good overview of existing work is provided by Toboso Sánchez, Deuda. Ruiz Martín, "Expediente" and "Finanzas," and Torres Lopez and Pérez-Prendes, Juros, also offer useful insights. For further discussion, see the online version of this article.

${ }^{30}$ The civil administration of overseas territories was generally covered by local revenue. Because these costs do not affect Castile's fiscal position, we do not include them in our calculation.

${ }^{31}$ Castilian spending on the Army of Flanders between 1580 and 1596 is only available as quinquennial totals (Parker, Grand Strategy). We do, however, have yearly data for the contributions paid by the Flemish treasury. To estimate annual expenditure by Castile, we assume that they moved in proportion with Flemish contributions. If we instead divide the quinquennial spending by five, our results are unaffected.
} 


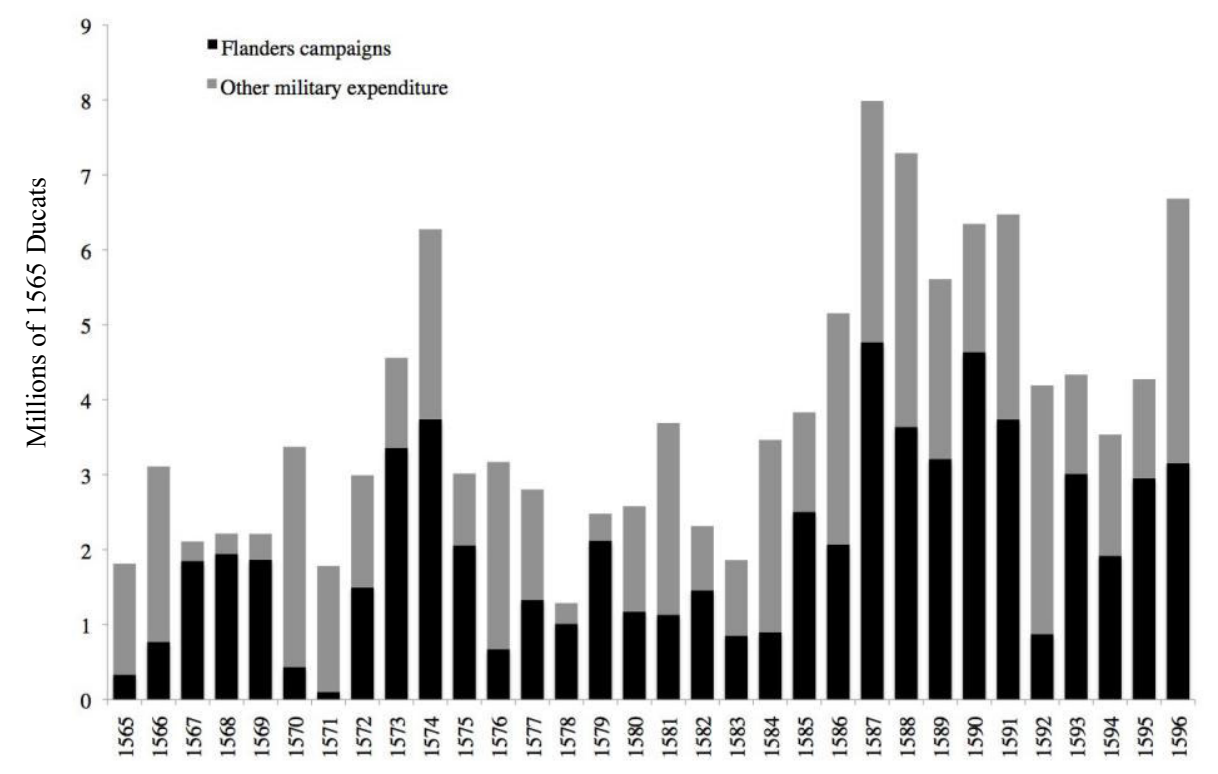

FIGURE 4

MILITARY EXPENDITURE

Sources: Calculation based on data from Dandelet, Roma and Spanish Rome; De Lamar, Diplomacy; Koenigsberger, Government; Lynch, "Philip II"; Parker, "Spain," Dutch Revolt, Spain, Grand Strategy, and Army; Tenace, Spanish Intervention and "Strategy"; and Thompson, War and Government and War and Society.

of the Dutch Revolt led to a spike in military outlays, which peaked in 1574 . The 1575 bankruptcy can be seen as its direct consequence. The following decade saw relatively limited military expenditure. This changed with the resumption of hostilities in the Netherlands in 1583. Expenditure continued to rise in the run-up and aftermath of the Armada. Outfitting it cost approximately ten million ducats, equivalent to roughly two years of total revenue. Following the disaster, a similar sum was spent on rebuilding the fleet to defend Spain against French and British attacks. The 1596 peak - the last year for which our sources allow a comprehensive assessment-reflects the response to the threat of invasion by the combined forces of France and England. 


\section{SUSTAINABILITY}

The previous section summarized available data derived from primary sources on revenues, short-term debt and the cost of servicing it, and military expenditure. There is also information on long-term debt and its servicing for individual years. For a comprehensive view of Castilian state finances, series are missing on nonmilitary expenditures, long-term debt service, and outstanding debt. We now estimate these series based on a combination of historical information, assumptions, and the logic of the government's budget constraint. We then go on to analyze the key features of fiscal performance under Philip II.

The government budget constraint can be written as

$$
\Delta d_{t}=d s_{t}-p s_{t}=E_{t}+d s_{t}-R_{t}=M E_{t}+N M E_{t}+d s_{t}^{l}+d s_{t}^{s}-R_{t}
$$

where $d$ is debt, $p s$ is the primary surplus (revenue minus nondebt expenditure), $d s$ is debt service, $d s^{l}$ and $d s^{s}$ denote long- and shortterm debt service, $R$ is revenue, $E$ is ordinary (non-debt) expenditure, $M E$ is military expenditure, and $N M E$ is nonmilitary expenditure. We have figures for total debt outstanding in 1565, 1575 and 1596. Because of the nature of the reschedulings, there was no short-term (asiento) debt in these years, and the long-term debt (juros) outstanding was equivalent to total debt. We thus know the change in total debt during the last 41 years of Philip's reign. We assume that the available information on long-term debt servicing costs (Table 1) is representative for the period as a whole. We interpolate debt servicing costs on juros linearly, using the data in Table $1 .{ }^{32}$ This gives us a series for $d s^{l}$. After summing up equation 1 over $t$, it is straightforward to solve for the sum of $N M E$, nonmilitary expenditure. The estimated sum of nonmilitary expenditure for the 1566-1596 period is 18.7 million ducats, compared to a total of 146.2 million ducats of military expenditure. To convert these estimates into annual figures, we assume that real nonmilitary spending was constant throughout Philip's reign. This is a plausible assumption, as most of the expenditures of the civil administration and internal law enforcement were fixed. ${ }^{33}$

We calculate outstanding debt by adding each year's fiscal balance to the previous year's debt stock. Total debt rose markedly slower than the sum of asientos issued suggests. Nominal debt increased by

\footnotetext{
${ }^{32}$ Interpolating the service on juros is not problematic. Juro issuance was capped by ordinary revenue, which grew slowly and smoothly (1575 was the exception). Since we have an actual observation for 1575 , our procedure captures the break in the trend.

${ }^{33}$ Nonmilitary spending was small overall; alternative assumptions have virtually no impact on final estimates.
} 
40.9 million ducats between 1565 and 1596 . Over the same period, the Crown entered into asiento loans for 92.1 million ducats. Thus, on average, a little less than half of asiento borrowing was either rolled over into new short-term loans or consolidated into long-term debt. Our total debt series closely matches the estimates for individual years in Table $1 .^{34}$ Table 2 gives an overview of our results. ${ }^{35}$

Revenues throughout Philip's reign were markedly higher than military and nonmilitary expenditure combined. Spending-excluding debt servicing costs - amounted to 76 percent of revenue in the $1560 \mathrm{~s}$ and early 1570 s, fell to 46 percent in the late 1570 s and early 1590 s, and then increased to 79 percent. Once we take debt servicing costs into account, the budget was on average in deficit during Philip's second and fourth decade on the throne, and in surplus during the third one. Nominal revenues grew by 52 percent between $1566-1574$ and 1575-1584, and by a further 22 percent over the next decade, for a total increase of 86 percent. Over the period as a whole, military expenditure more than doubled, and debt increased by 78 percent.

In real terms, Philip's revenues grew by 53 percent over the entire period (Panel B), while non-debt expenditure increased by 62 percent. In 1575-1584 real military spending had fallen 14 percent relative to 1566-1574. Philip earned a "peace dividend" after the successful battle of Lepanto and the lull in the Dutch Revolt. Castile's budget swung into surplus as a result, having been in deficit in the years 1566-1574. This surplus gave way to annual deficits of more than two million ducats (in 1565 prices) in the period $1585-1596$. During that period, military spending more than doubled, driven by the Armada and renewed fighting in the Low Countries. In real terms, Philip's overall debts rose by 47 percent between the second and fourth decade of his reign-less than the increase in revenues.

Arguably, scaling by an economy's total output is the right way to measure the burden of military commitments and debt. However, estimating sixteenth-century GDP is difficult - the latest published estimates for Castile differ by more than 200 percent between their upper and lower bounds. ${ }^{36}$ Because of the substantial uncertainty surrounding Castilian GDP, we use revenue as a scaling magnitude. Military spending was flat relative to revenue-although with strong fluctuations. The debt burden rose marginally. Total debt servicing cost amounted to 60 percent

\footnotetext{
${ }^{34}$ The mean absolute difference between our estimates of total debt stock and total juro borrowing (matched to the nearest year) is 2.1 percent of our estimate.

${ }^{35}$ For the full set of fiscal accounts, see the online version of the article.

${ }^{36}$ Alvarez Nogal and Prados de la Escosura, "Decline."
} 
TABLE 2

FISCAL ACCOUNTS, 1566-1596

(period averages)

\begin{tabular}{|c|c|c|c|}
\hline & $1566-1574$ & $1575-1584$ & $1585-1596$ \\
\hline \multicolumn{4}{|c|}{ Panel A (nominal, million of ducats) } \\
\hline Revenues & 5.17 & 7.88 & 9.60 \\
\hline Military expenditure & 3.40 & 3.04 & 6.95 \\
\hline Nonmilitary expenditure & 0.54 & 0.59 & 0.66 \\
\hline Primary surplus & 1.24 & 4.25 & 1.99 \\
\hline Long-term debt service & 2.35 & 3.00 & 3.91 \\
\hline Short-term debt service & 0.77 & 0.47 & 0.79 \\
\hline Fiscal balance & -1.89 & 0.78 & -2.71 \\
\hline Outstanding debt & 30.35 & 37.37 & 54.07 \\
\hline \multicolumn{4}{|c|}{ Panel B (real, million of 1565 ducats) } \\
\hline Revenue & 4.93 & 6.96 & 7.52 \\
\hline Military expenditure & 3.18 & 2.67 & 5.48 \\
\hline Nonmilitary expenditure & 0.52 & 0.52 & 0.52 \\
\hline Primary surplus & 1.23 & 3.77 & 1.53 \\
\hline Long-term debt service & 2.23 & 2.65 & 3.06 \\
\hline Short-term debt service & 0.72 & 0.41 & 0.62 \\
\hline Fiscal balance & -1.72 & 0.71 & -2.15 \\
\hline Outstanding debt & 28.75 & 32.96 & 42.24 \\
\hline \multicolumn{4}{|l|}{ Panel C (\% of revenue) } \\
\hline Military expenditure & 65.8 & 38.6 & 72.4 \\
\hline Nonmilitary expenditure & 10.4 & 7.5 & 6.9 \\
\hline Primary surplus & 24.0 & 53.9 & 20.7 \\
\hline Long-term debt service & 45.5 & 38.1 & 40.7 \\
\hline Short-term debt service & 14.9 & 6.0 & 8.2 \\
\hline Fiscal balance & -36.6 & 9.9 & -28.2 \\
\hline Outstanding debt & 587.0 & 474.2 & 563.2 \\
\hline
\end{tabular}

Sources: See discussion in text and Appendix E in the online version of this article. The deflator used to obtain the real values in Panel B is the Old Castilian price index from Drelichman, "Curse." Panel C was derived from Panel A.

of revenue in the first decade. This fell to 44 percent in the second one, and rose slightly to 49 percent in the last one. For the period as a whole, Philip II ran average fiscal deficits of approximately 20 percent of revenue. While the average deficit in the first period had amounted to 37 percent, the second period saw surpluses of 10 percent of revenue. The decade of the Armada saw a return to deficits of 28 percent on average. 


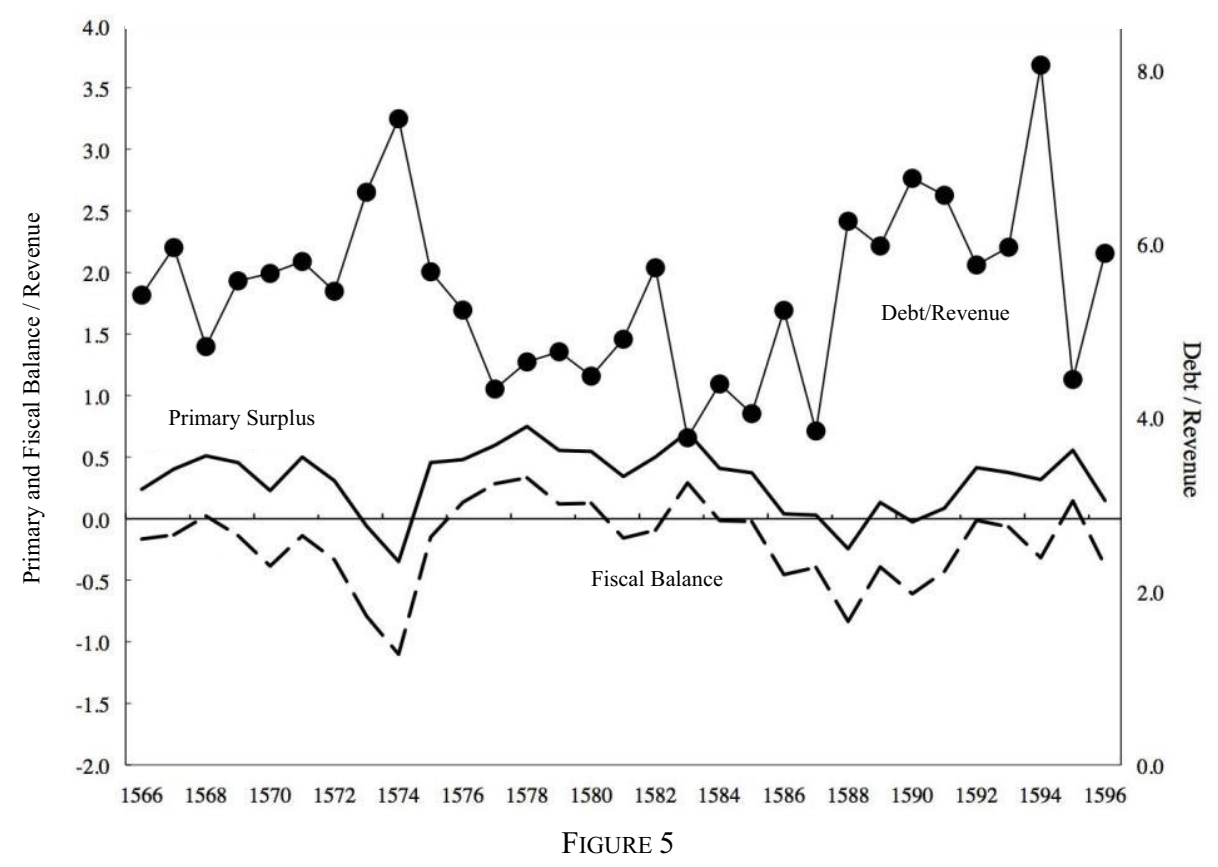

BUDGET BALANCE AND DEBT/REVENUE, 1566-1596

Sources: See the online version of this article.

Figure 5 shows the primary surplus and fiscal balance side-by-side. The run-ups to the bankruptcy in 1575 and to the Armada are associated with primary deficits. After the rescheduling in 1577 and the large tax hike agreed by the Cortes, surpluses became substantial, varying between 50 and 70 percent of revenue. This return to large (primary and overall) surpluses was aided by lower military expenditure. Similarly, the new excises (the millones) improved Castile's fiscal position in the 1590s. Overall, Castile ran primary surpluses equivalent to 32 percent of revenues. Despite almost continuous warfare, Philip II almost never borrowed to pay interest. Instead, a substantial proportion of his revenues was available for servicing his debts, year after year. The only exceptions to this were periods of exceptional military effort - the great Dutch offensive of the early 1570 s, and the Armada. ${ }^{37}$

That money formed the "sinews of power," in Cicero's famous phrase, is reflected in the effects of war on overall fiscal balance. Revenues could fluctuate from year to year, and did so largely as a result of silver windfalls or shortfalls. Debt servicing costs fluctuated,

\footnotetext{
${ }^{37}$ Figure 5 speaks against the "serial default" literature. The 1575 payment stop did not lead to a downward spiral of weakening fiscal institutions, as predicted by Reinhart, Rogoff, and Savastano, "Debt." Instead, primary surpluses increased.
} 
depending on the mix of short- and long-term debt, and the financing conditions in each market. Yet the prime determinant of the Crown's fiscal position was the scale of its military effort. If we regress $p s_{t}$ on $M E_{t}$, we obtain a coefficient of -1.07 ( $t$-statistic 9.4) ${ }^{38}$

For public debt to be sustainable, revenue and expenditures have to allow the servicing of debts in the future. Debt-to-income ratios should not rise above levels that are typically considered sensible, given the development of the tax system and public debt administration. Philip II's debts did not increase relative to revenue. Taking period averages, they fell from 5.9 times annual revenue in 1566-1574 to 4.8 times in $1575-1584$, before rising to 5.7 times in the final decade. There is therefore no evidence of a growing fiscal crisis - revenues rose faster than debt.

A more systematic approach examines sustainability through the lens of primary surpluses necessary to stabilize the debt-to-income ratio. For spending and borrowing to be sustainable, the long-run level of the debt to GDP ratio ought to be stable. This requires that the government keep expenditure (net of the cost of debt service) below revenue. A low cost of borrowing and revenue growth can facilitate a favorable outcome. We use the following debt accumulation equation

$$
\Delta d_{t}=p d_{t}^{*}+\frac{\left(r_{t}-g_{t}\right)}{\left(1+g_{t}\right)} d_{t-1}=0 \Leftrightarrow-p d_{t}^{*}=p s_{t}^{*}=\frac{\left(r_{t}-g_{t}\right)}{\left(1+g_{t}\right)} d_{t-1}
$$

where $\Delta d$ is the change in the debt to income ratio, $r$ is the (nominal) rate of interest, $g$ is the growth rate of GDP, $p d$ is the primary deficit, and $p s^{*}$ is the primary surplus that will reduce $\Delta d$ to zero, thus holding the debt-to-income ratio constant. ${ }^{39}$

The approach in equation 2 can be criticized because the "maximum" level of debt is not well defined. The International Monetary Fund therefore proposes the following simple measure of sustainable debt:

$$
D^{*}=P S /(r-g)
$$

where $D^{*}$ is the sustainable debt level. ${ }^{40}$ The right-hand side is simply the discounted value of future primary surpluses, where the discount rate is calculated as the difference between interest payments and the

\footnotetext{
${ }^{38}$ Using the Newey-West correction does not change results. For three lags, the $t$-statistic is 11.6; for $5,13.5$.

${ }^{39}$ Aizenman and Pinto, Managing Economic Volatility.

${ }^{40}$ IMF, World.
} 
TABLE 3

SUSTAINABILITY CALCULATIONS: BASELINE RESULTS

\begin{tabular}{rrrrrrrrr}
\hline \hline & $\begin{array}{c}g \\
(\%)\end{array}$ & $\begin{array}{c}r \\
(\%)\end{array}$ & $P S^{*}$ & $P S$ & $P S-P S^{*}$ & $D^{*}$ & $D$ & $D-D^{*}$ \\
\hline $1565-1574$ & 3.38 & 10.20 & 0.394 & 0.249 & -0.145 & 3.645 & 5.863 & 2.218 \\
$1574-1584$ & 3.28 & 9.30 & 0.433 & 0.454 & 0.020 & 7.534 & 4.787 & -2.748 \\
$1584-1596$ & 3.44 & 8.80 & 0.227 & 0.201 & -0.026 & 3.744 & 5.728 & 1.983 \\
$1565-1596$ & 3.37 & 9.40 & 0.348 & 0.315 & -0.033 & 5.229 & 5.476 & 0.246
\end{tabular}

Notes: The growth rate of revenue is $g, r$ is the interest rate, $P S$ is the actual primary surplus relative to revenue, $P S^{*}$ is the surplus required for stabilizing the debt-to-revenue ratio, $D$ is actual debt/revenue, and $D^{*}$ is the debt-to-revenue ratio that can be sustained given actual primary surpluses. Growth rates are calculated as annualized compounded rates of growth between benchmark dates. Hence, the overall rate is not equivalent to the weighted average of the growth rates in subperiods.

growth rate. The higher the primary surplus and the growth rate of income, the larger the debt that can reliably be serviced.

Sustainability analyses are typically performed using GDP to scale fiscal variables. We scale by revenue instead. This is because early modern government finances are probably best judged not relative to national production, but by revenues actually generated. ${ }^{41}$

Table 3 shows our baseline sustainability results, comparing required and actual primary surpluses, as well as possible and actual debt levels. The analysis is performed by decade, and for Philip II's reign overall. Primary surpluses for the period as a whole were sufficient to keep upward pressure on the debt-to-revenue ratio in check. The primary surplus required to stabilize the debt to revenue ratio was 35 percent of revenue, which is only slightly higher than the number attained-31.5 percent. At the time of his death, the Crown's debt in relation to revenue stood where it had been 33 years earlier-at a multiple of less than six. Average sustainable debt was 5.2 times revenue, and actual levels stood at 5.5 times - a minor difference.

During the first decade, primary surpluses were about two-thirds of the level necessary for stability. Interest rates were relatively high, and revenue grew moderately. Debt levels were higher than could be sustained ad infinitum. The second decade, from 1575 to 1584 , showed a decline in interest rates and a higher growth rate of revenue. Reduced military spending allowed primary surpluses to increase markedly. They were now higher than necessary to stabilize debt levels. Actual indebtedness was below the maximum sustainable level. In the

\footnotetext{
${ }^{41}$ In our robustness tests, reported in the online version, we use several measures of GDP.
} 
final decade, military events caused expenditure to increase again. The primary surplus required for stability fell to 0.23 , which is 3 percentage points (of revenue) higher than the actual number. For the period as a whole, sustainability overall was not compromised despite near-continuous warfare and major military efforts in the last two decades of the sixteenth century.

Our conclusion that Philip II's finances were largely sustainable rests on newly collected data, a reworking of existing estimates, and the derivation of information from combining these different series. At each step, we made assumptions that may affect our assessment. Our results are nonetheless robust to a number of alternative scenarios. In particular, they survive using alternative measures of revenue growth rates; replacing revenue by the best available estimates of GDP as a scaling variable; ignoring the reductions in debt stock generated by the defaults; and using different estimates for the cost of short-term debt service. We provide a full sustainability assessment under each alternative scenario in the online version of this article.

\section{COUNTERFACTUAL - THE VALUE OF VICTORY IN THE LOW COUNTRIES}

With hindsight, we know that the Armada marked a turning point for the worse in Philip II's finances. Ex ante, it was by no means clear that Spain-which had recently routed the Ottoman fleetwould fail. While some contemporaries were pessimistic about the Armada's prospects, others took it very seriously. Sir Walter Raleigh (together with Sir Richard Grenville) was charged with the defense of Devon and Cornwall against the Armada. Writing in 1614, he observed that England was "of no such force as to encounter an Armie like unto that, wherewith it was intended that the prince of Parma should have landed in England." 42 As Geoffrey Parker observes, had the Armada even met with limited success, Spain would have reaped large benefits. Attempting to subdue the Dutch Rebellion was arguably different. While the Armada was inspired by the need to make progress in Flanders, protracted attempts to reconquer Holland cannot be construed as an unexpected expenditure shock. We argue that the benefits from peace in Holland and Zeeland were such that even the prolonged efforts of the Spanish Crown there were not inappropriate in an economic sense. Any victory, even at a late stage, would have allowed a rapid improvement of Philip II's finances.

\footnotetext{
${ }^{42}$ Quoted in Parker, Spain.
} 
If the chance of ultimate success was higher than zero, then the fiscal outcome that we document constitutes a lower bound on the sustainability of Castilian finances, reflecting the worst-case scenario in military terms. Ex ante, it is not clear why Philip and his advisors should not have entertained reasonable hopes of suppressing the Dutch rebellion. Few large populous areas had ever broken away from central control in Europe-Switzerland being a notable exception. Philip's empire was the superpower of the age. Many contemporaries were convinced that Spain would eventually prevail. A successful conclusion of Philip II's campaign in the Low Countries would have allowed a marked reduction in military expenditure. In addition, it may have yielded extra revenue as a result of being able to tax the rebellious provinces. We hazard conservative guesses for both figures, and argue that relatively small changes to actual expenditure and revenue would have had a considerable impact on the overall state of Philip II's finances.

The lull in fighting after the sack of Antwerp in 1576 illustrates how much Castilian finances could change as a result of reduced military efforts. During the period 1566-1596, Philip II spent 163 million ducats on non-debt expenditures, of which 144.3 went to military expenses. Of this, fully 53 percent - 77.3 million ducats - was spent on the Army of Flanders. During the Armada and its aftermath, from 1587 to 1596, expenditure in the Low Countries amounted to 40.6 million ducats. During the ten preceding years, when no major military operations took place, total expenditure on the Army of Flanders was 16.8 million ducats, 59 percent less. We assume that, had the Armada succeeded, military expenditure after a Spanish victory would have been similar to the figures for 1577-1586. Thus, some 17.6 million ducats could probably have been saved from 1589 on. Note that our calculations provide a lower bound on the reduction in expenses that would have followed the Armada's success, as our figures continue to count the cost of rebuilding the decimated Atlantic fleet. Excluding it would have saved another 5.56 million ducats after $1588 .^{43}$

Additional tax revenue is a more speculative source of improvement in Philip II's finances. Victory over the rebellious provinces would have allowed Philip to tax them. We take the estimates of tax revenue in Holland compiled by Wantje Fritschy. To err on the side of caution, we assume that Castile would not have been as efficient in taxing its reluctant subjects as they were themselves. Therefore, we reduced the tax estimates by 50 percent. Accordingly, most of the change in Philip's

\footnotetext{
${ }^{43}$ Victory in Flanders could have worsened Philip's fiscal position only if it had led to even more, high-intensity warfare with England. While not impossible, we consider this unlikely. Figures are from Parker, Grand Strategy.
} 


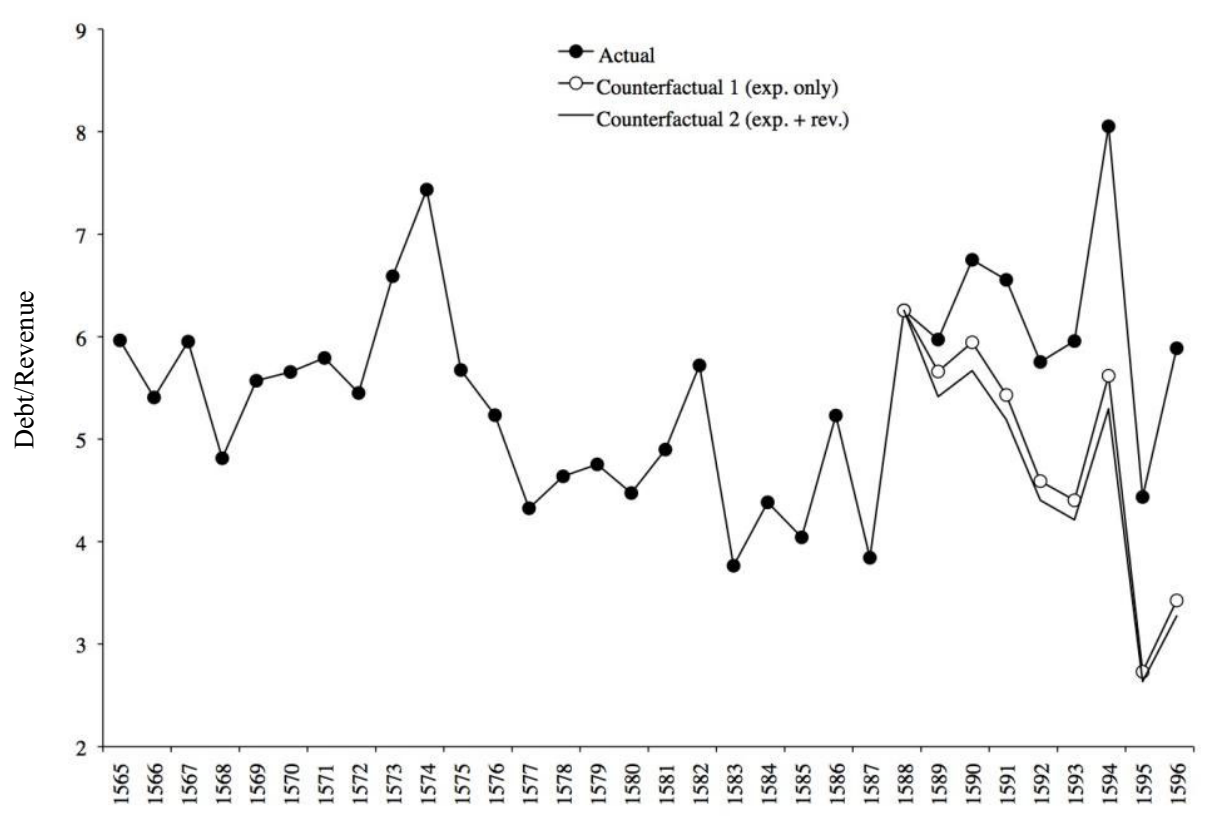

FIGURE 6

VICTORY IN FLANDERS - COUNTERFACTUAL DEBT/REVENUE PATHS

Sources: See the text.

fiscal position would have reflected lower expenditure (saving 2.5 million ducats in 1596) than higher revenue (adding 0.53 million). ${ }^{44}$

To examine the impact of lower expenditure and higher revenue on such a scale, we recalculate overall expenditure, the fiscal balance, primary surpluses, and total debt, for each year. As a result of victory in the Low Countries, Philip could have ended his reign with debts of 39 million ducats instead of 66 million. The debt-to-revenue ratio would have resumed the downward trend it was on before the plan for the Armada was put into motion. Figure 6 shows the two counterfactuals. The first uses only lower military expenditure, while the second adds possible revenue from Holland.

The key reason why Philip's finances would have looked healthy by the end of his reign would have been less war, not more taxes. Thus, the Armada made good sense in fiscal terms ex ante. This is not to say that fiscal considerations were key. It simply implies that religion or strategy need not be the only motives why the Armada seemed a promising project at the time.

\footnotetext{
${ }^{44}$ This is a conservative calculation. We do not know how much money a victorious Habsburg Empire would have extracted from the Dutch provinces. Dutch taxes on themselves averaged 2.6 million ducats in 1600-1650 (Fritschy, “Financial Revolution"”). In the final year of his reign, Philip's total revenue was 11.3 million ducats.
} 


\section{INTERNATIONAL COMPARISONS}

We now compare the state of Castile's finances with that of other major European states at the height of their power, using a variety of indicators. We chose three cases-Holland, France, and Britain. Table 4 gives an overview, drawing on a variety of sources from Bonney's European State Finance Database.

A measure often used in assessing the strength of fiscal systems is the debt service-to-revenue ratio. ${ }^{45} \mathrm{We}$ explore Castile's position relative to that of other early modern European powers. ${ }^{46}$ The Netherlands marks one extreme with an average debt service-to-revenue ratio of 68 percent. ${ }^{47}$ France is at the opposite end of the spectrum, with a relatively low ratio of 38 percent in the eighteenth century. ${ }^{48}$ However, this excludes the period prior to the 1720 rescheduling, when servicing costs reached 80 percent of revenue. Sixteenth-century Castile has a ratio of 51 percent. This makes it more similar to the United Kingdom than to the Netherlands. ${ }^{49}$ Compared to the other great powers in early modern Europe, Castile was not spending a particularly high proportion of its revenue on debt service.

The same conclusion emerges when we examine the maximum debt service-to-revenue ratio. This ratio peaks at 75 percent for Castile, and at 70 percent for Britain. ${ }^{50}$ France saw a maximum of 81 percent. ${ }^{51}$ The Netherlands sustained very high levels of close to 200 percent for a short period while it accumulated debts during the War of the Spanish Succession.

Castilian tax revenues grew quickly-more quickly than in the United Kingdom or Holland. If we compare the Castilian figure with tax increases in the other countries, we see that fiscal pressure grew at a high rate-approximately twice as fast as in the United Kingdom during the eighteenth century. This is all the more remarkable since

\footnotetext{
${ }^{45}$ Sargent and Velde, "Macroeconomic Features."

${ }^{46}$ Our data allows us to compare Castile to other European imperial powers when each was at the peak of their power. Yun Casalilla, Marte, compares Castile to other contemporary European nations.

${ }^{47}$ Calculated from the data in the European State Finance Database compiled by t'Hart, "United Provinces."

${ }^{48}$ Inferred from Figure 1 in Sargent and Velde, "Macroeconomic Features."

${ }^{49}$ We compare the cases of Spain and the United Kingdom in somewhat greater depth in Drelichman and Voth, "Debt Sustainability."

${ }^{50}$ By 1815 Britain's debt/GDP reached 185 percent, according to Barro, "Government." We exclude the Napoleonic Wars. This biases our results against finding high fiscal pressure in France and Britain.

${ }^{51}$ By the late eighteenth century, France had a lower ratio than Britain, amounting to 52 percent in 1788 (White, "French Revolution").
} 
TABLE 4

INTERNATIONAL COMPARISONS

\begin{tabular}{lcccc}
\hline & $\begin{array}{c}\text { United } \\
\text { Kingdom**** }\end{array}$ & Netherlands & Castile & France \\
\hline Average debt service/Revenue (\%) & 43 & 68 & 51 & 38 \\
& $(1698-1793)$ & $(1601-1712)$ & $(1566-1596)$ & $(1720-1780)$ \\
Maximum debt service/Revenue (\%) & 70 & 194 & 75 & 81 \\
& $(1784)$ & $(1713)$ & $(1574)$ & $(1718)$ \\
Growth rate of revenue (\%) & 1.47 & 0.36 & 3.30 & $1.26^{++}$ \\
& $(1692-1794)$ & $(1601-1712)$ & $(1566-1596)$ & $(1661-1717)$ \\
Primary surplus/Revenue (\%) & 19.5 & negative & 31.50 & $14.2^{++}$ \\
& $(1698-1794)$ & & $(1566-1596)$ & $(1662-1717)$ \\
Revenue/GDP (\%) & 9.1 & $21.2^{+}$ & $2.7^{*}-9.5^{* *}$ & $6.8^{* * *}$ \\
Debt/GDP (\%) & & & & $(1788)$ \\
& $(1698-1793)$ & & $(1566-1596)$ & $(1789)$ \\
\hline
\end{tabular}

${ }^{+}$Per capita tax as a percentage of income of an unskilled laborer, as calculated by De Vries and Woude, First Modern Economy.

${ }^{++}$Based on data used for Velde, "John Law's"; as provided by the author.

+++ Sargent and Velde, "Macroeconomic Features"; table 1.

* GDP based on the lower bound in Alvarez Nogal and Prados de la Escosura, "Decline."

** GDP from Carreras, "Modern Spain."

*** Based on data by Weir, "Tontines"; as compiled by Crafts, "Exogenous or Endogenous Growth."

**** GDP data from Crafts, "Exogenous or Endogenous Growth."

Notes: Data taken from Bonney, European State Finance Database. Fiscal data from Mitchell, British Historical Statistics.

historians have long held up Britain's willingness to raise taxes as one of the key factors for its success in the wars with France. ${ }^{52}$ Maximum fiscal pressure in Britain and Castile was comparable even if we use the most pessimistic GDP figures for the latter. Using the most recent estimates by Carlos Alvarez Nogal and Leandro Prados de la Escosura, revenue/GDP was half of the British figure, and markedly lower than in Holland. Debt/GDP ratios (tentative as they are) suggest that total indebtedness in Spain was markedly less than in the United Kingdom. Castile's primary surpluses were very high, even by the elevated English and French standards. ${ }^{53}$ Scaling by revenue does not alter our conclusions. In 1801, for example, Britain's debt stood at a

\footnotetext{
${ }^{52}$ Brewer, Sinews; and O'Brien, "Mercantilist Institutions."

${ }^{53}$ Prerevolutionary France also returned to primary surpluses, if only for a time. See White, "Was There a Solution?"
} 
multiple to revenue of $13.7 .{ }^{54}$ Our findings about the relative fiscal health of European powers echo those of White. ${ }^{55}$

We conclude from international comparisons that there was ample room for Castile's tax/GDP ratio to grow, and grow it did. Strikingly, ordinary expenditure did not catch up with revenue. While Castile's fiscal infrastructure was not as highly developed as Holland's or Britain's, revenue growth provided breathing room to cope with high debts. Castile's success in raising revenue was a key determinant of its high primary surpluses. These in turn underpinned the ability to service debts.

\section{CONCLUSION}

In this article, we present comprehensive annual fiscal accounts for Castile between 1566 and 1596. These series are based on new archival data, earlier estimates, and a simple national accounting framework. Hand-collected data on short-term borrowing allows us to derive debt servicing costs. Based on these, we calculate deficit figures and fiscal surpluses, as well as an annual series of debt outstanding. Our estimates represent the earliest reconstruction of full annual fiscal accounts for any state in history.

"Military overstretch" has served as a key explanation for the rise and fall of great powers. Also, a series of defaults is often viewed as detrimental to the development of a country's institutions and economy. For both hypotheses, sixteenth-century Castile has been used as a prime example. Our new data show that Castile's fiscal position was much healthier than is commonly believed. The fragmentary nature of existing evidence, combined with eye-catching defaults, created a negative impression that is not supported by a detailed reconstruction of Philip II's finances. Debt rose during his reign, but so did revenue; debt-to-revenue ratios stayed broadly constant. Far from excess fiscal pressure undermining the foundations of Spanish imperial might, rising revenue simply kept up with growth in population and incomes. ${ }^{56}$ This, in itself, is a remarkable fact. While some years saw high expenditurereflecting the Duke of Alba's big push in the Netherlands, and the Invincible Armada-Philip II's wars did not put state finances on an unsustainable path. This is partly because the growth of expenditures lagged behind the rise in revenues. While debt accumulated, primary surpluses grew. Philip II ran primary surpluses in all but three years of

\footnotetext{
${ }^{54}$ Mitchell, British Historical Statistics. In 1822 the ratio still stood at 12.96.

${ }^{55}$ White, "France."

${ }^{56}$ On this point, see also Bilbao, "Ensayo."
} 
his reign, helping the debt-to-revenue ratio remain constant over time. We conclude that Spanish debts were sustainable throughout.

In comparison to other early modern European states, Castile's finances in the sixteenth century were not particularly strained. Although it spent more than the United Kingdom on servicing its debts (relative to GDP), Castile fared better than the Dutch Provinces. And while total tax pressure was similar to the United Kingdom, maximum debt relative to revenue was actually lower. Castile's fiscal performance was sustained by restrained expenditure, resulting in consistently large primary surpluses. These amounted to almost a third relative to revenues - a much higher ratio than in the United Kingdom.

In light of our findings, the bankruptcy of 1575 appears as little more than a temporary setback. The suspension of payments was triggered by a strong increase in military expenditures in the two preceding years. The 1576 tax increase and the 1577 settlement effectively corrected the problem. Between 1577 and 1584 the fiscal indicators behaved similarly to the preceding two decades; growing debt was met with an increasing primary surplus, and the deficit was kept under control. While the period after the 1575 bankruptcy saw consolidation, the fiscal situation deteriorated somewhat after 1588, when Philip decided to undertake the "Enterprise of England." The enormous cost of outfitting the Armada sent the budget into the red, virtually eliminating the primary surplus. After 1588 the threat of British attacks required more military spending. The introduction of new excises and record silver remittances ameliorated the king's fiscal position, but the outbreak of the Elizabethan war halted any significant improvement in Castile's finances. Yet, despite these stringencies, the final bankruptcy in 1596 involved smaller "haircuts" for lenders and affected a smaller amount of debt than in 1575. At the time of Philip's death, the debt-to-revenue ratio was actually lower than it had been in 1566 .

That Castile's debts were sustainable is an important finding for the history of sovereign debt. The king clearly could pay his bankers, given the overall health of his finances. With this result in hand, the next question is why a powerful monarch like Philip II mostly honored his debts? Our findings thus prepare the ground for other studies that examine what sustained sovereign lending in the case of early modern Castile. James Conklin concluded that Genoese bankers could punish Philip by withholding transfer services. Alvarez Nogal argued that a centrally promoted cooperative market structure was responsible for access to credit. ${ }^{57}$ Elsewhere, we conclude that the sanctions view is not supported

\footnotetext{
${ }^{57}$ Conklin, "Theory"; and Alvarez Nogal, "Role."
} 
by the evidence. Instead, the importance of access to funds in the future, combined with incentives for lenders not to undermine a moratorium in case of default, made lending sustainable. ${ }^{58}$

Our results also shed light on the nature of serial defaults. Reinhart, Rogoff, and Savastano argue that countries go bankrupt repeatedly because deeper parameters in their political and social environment make repayment difficult. Borrowing, for them, can be unsafe even at low levels. Default episodes may have important negative knock-on effects on growth and the quality of fiscal institutions. Chris Sims points out that even serial defaults may be an efficient equilibrium outcome, and that there is only limited evidence that bankruptcies harm fiscal institutions. ${ }^{59}$ Spain's history of 13 defaults between 1550 and 1900 serves as a prime example in the serial defaults literature. Our results suggest Castile's early defaults occurred at a time of reasonable fiscal probity and broadly healthy financial conditions. While it is possible that the effect of later Spanish bankruptcies undermined its fiscal and economic position, the events in our period do not suggest that the quality of fiscal institutions suffered. Since the king used the defaults as a negotiating device to raise taxes on the cities, suspensions ultimately helped strengthen the fiscal powers of the Spanish state.

During the period of our study, the Spanish empire was at the height of its powers. It also saw the forging of Philip II's "grand strategy" and the unraveling of Spanish hegemony in the wake of military setbacks. ${ }^{60}$ To contemporaries, it was not clear that Philip II's strategy in the Netherlands would fail. Had it succeeded, the vast military expenditures used in the ultimately futile bid to subdue the rebels could have been saved. In addition, the rich cities of the Low Countries might have been taxed. Had the invasion of England been carried out successfully, the Crown would have saved the expense of building a second fleet, and possibly gained additional tax revenue. The defeat of 1588 dealt a sharp blow to Castile's military and financial position. In this sense, hopes of servicing all debts to the letter of each contract did not flounder on the rocks of fiscal recklessness and ineptitude, as suggested by earlier scholarship. They sank together with the Armada's ships in the English Channel. These findings suggest that bankers need not have been foolish or exuberantly optimistic to lend to Philip II. Ex ante, their chances of being repaid were probably at least

\footnotetext{
${ }^{58}$ See Drelichman and Voth, "Lending to Borrower." Important contributions to the theory of sovereign debt using historical episodes include Tomz, Reputation; Mitchener and Weidenmier, "Supersanctions"; and Eichengreen and Portes, "Settling Defaults."

${ }^{59}$ Sims, "Comments."

${ }^{60}$ Parker, Grand Strategy.
} 
as high as those of investors in British consols in the early nineteenth century. At that point in time, British government debt had reached almost two times GDP. ${ }^{61}$ That Spain would eventually hold the record for serial default, and that Britain would emerge as a textbook example of fiscal probity, may owe more to success or misfortune on the battlefield than to differences in "fiscal discipline."

${ }^{61}$ Barro, "Government."

\section{REFERENCES}

Aizenman, Joshua, and Brian Pinto. Managing Economic Volatility and Crises: A Practitioner's Guide. Cambridge: Cambridge University Press, 2005.

Alvarez Nogal, Carlos. "The Role of Institutions to Solve Sovereign Debt Problems: The Spanish Monarchy's Credit (1516-1665).” Working Paper, Universidad Carlos III de Madrid, 2003.

Alvarez Nogal, Carlos, and Leandro Prados de la Escosura. "The Decline of Spain (1500-1850): Conjectural Estimates.” European Review of Economic History 11, no. 3 (2007): 319-66.

Artola, Miguel. La Hacienda del Antiguo Régimen. Madrid: Alianza, 1982.

Barro, Robert J. "Government Spending, Interest Rates, Prices, and Budget Deficits in the United Kingdom, 1701-1918." Journal of Monetary Economics 20, no. 2 (1987): 221-47.

Bilbao, Luis María. "Ensayo de reconstrucción histórica de la presión fiscal en Castilla durante el Siglo XVI." In Haciendas Forales y Hacienda Real: homenaje a Miguel Artola y Felipe Ruiz Martín, edited by Fernández de Pinedo y Emiliano Fernández, 37-61. Universidad del País Vasco, 1990.

Bonney, Richard. The Rise of the Fiscal State in Europe, c. 1200-1815. Oxford: Oxford University Press, 1999.

. European State Finance Database. 1995-2007. http://www.le.ac.uk/hi/bon/ESFDB/ (accessed 23 August 2007).

Braudel, Fernand. The Mediterranean and the Mediterranean World in the Age of Philip II. Second Revised Edition. Glasgow: William Colins \& Sons, 1966.

Brewer, John S. The Sinews of Power. Cambridge, MA: Harvard University Press, 1988.

Carande, Ramón. Carlos Vy sus banqueros. 3 vols. Barcelona: Crítica, 1987.

Carlos Morales, Carlos Javier de. Felipe II: El Imperio en Bancarrota. Madrid: Dilema, 2008.

Carreras, Albert. "Modern Spain." In The Oxford Encyclopedia of Economic History, edited by J. Mokyr, 546-53. New York: Oxford University Press, 2003.

Carretero Zamora, Juan Manuel. Cortes, monarquía, ciudades: Las Cortes de Castilla a comienzos de la época moderna (1476-1515). Madrid: Siglo XXI, 1988.

Conklin, James. "The Theory of Sovereign Debt and Spain Under Philip II." Journal of Political Economy 106, no. 3 (1998): 483-513. 
Crafts, N. F. R. "Exogenous or Endogenous Growth? The Industrial Revolution Reconsidered." The Journal of Economic History 55, no. 4 (1995): 754-72.

Dandelet, Thomas James. Roma Hispanica: The Creation of Spanish Rome in the Golden Age. Ph.D. Diss., University of California, Berkeley, 1995. . Spanish Rome, 1500-1700. New Haven, CT: Yale University Press, 2001.

De Lamar, Jensen. Diplomacy and Dogmatism: Bernardino de Mendoza and the French Catholic League. Cambridge, MA: Harvard University Press, 1964.

De Vries, Jan, and Ad Van der Woude. The First Modern Economy. Cambridge: Cambridge University Press, 1997.

Drelichman, Mauricio. "The Curse of Montezuma: American Silver and the Dutch Disease." Explorations in Economic History 42, no. 3 (2005): 349-80.

Drelichman, Mauricio, and Hans-Joachim Voth. "Debt Sustainability in Historical Perspective: The Role of Fiscal Repression." Journal of the European Economic Association 6, no. 2-3 (2008): 657-67.

"Institutions and the Resource Curse in Early Modern Spain." In Institutions and Economic Performance, edited by E. Helpman, 120-47. Cambridge, MA: Harvard University Press, 2008. . "Lending to the Borrower from Hell: Debt and Default in the Age of Philip II, 1556-1598." Working Paper, University of British Columbia, Vancouver, 2010. . "Serial Defaults, Serial Profits: Returns to Sovereign Lending in the Age of Philip II." Working Paper, University of British Columbia, Vancouver, 2010.

Eichengreen, Barry, and Richard Portes. "Settling Defaults in the Era of Bond Finance." World Bank Economic Review 3, no. 2 (1989): 211-39.

España. Ministerio de Cultura. Archivo General de Simancas. Sections: "Contadurías Generales 2a Epoca" and "Consejo y Juntas de Hacienda."

Ferguson, Niall. The Cash Nexus: Money and Power in the Modern World, 17002000. New York: Basic Books, 2002.

Fortea Perez, José Ignacio. Las Cortes de Castilla y León bajo los Austrias: una interpretación. Junta de Castilla y León, 2009.

Fritschy, W. “A ‘Financial Revolution' Reconsidered: Public Finance in Holland During the Dutch Revolt, 1568-1648." Economic History Review 56, no. 1 (2003): 57-89.

Gelabert, Juan. "Castile, 1504-1808." In The Rise of the Fiscal State in Europe, c. 1200 1815, edited by R. Bonney, 201-42. Oxford: Oxford University Press, 1999.

Grossman, Herschel I., and John B. Van Huyck. "Sovereign Debt as a Contingent Claim: Excusable Default, Repudiation, and Reputation." American Economic Review 78, no. 5 (1988): 1088-97.

Hamilton, Earl J. American Treasure and the Price Revolution in Spain, 1501-1650. Cambridge, MA: Harvard University Press, 1934.

Hoffman, Philip T., and Kathryn Norberg. Fiscal Crises, Liberty, and Representative Government, 1450-1789. Stanford, CA: Stanford University Press, 1994.

International Monetary Fund. World Economic Outlook. Washington: IMF, 2003.

Jago, Charles. "Habsburg Absolutism and the Cortes of Castile." The American Historical Review 86, no. 2 (1981): 307-26.

"Philip II and the Cortes of Castile: The Case of the Cortes of 1576." Past \& Present 109 (1985): 22-43.

Kennedy, Paul M. The Rise and Fall of the Great Powers: Economic Change and Military Conflict from 1500 to 2000. New York: Random House, 1987.

Koenigsberger, H. G. The Government of Sicily Under Philip II of Spain: A Study in the Practice of Empire. London: Staples, 1951. 
Lapeyre, Henri. Simón Ruiz et les "asientos" de Philippe II. Paris: Librairie Armand Colin, 1953.

Las Cortes de Castilla y León en la Edad Moderna. Valladolid: Cortes de Castilla y León, 1989.

Lovett, A. W. "The Castilian Bankruptcy of 1575." The Historical Journal 23, no. 4 (1980): 899-911.

. "The General Settlement of 1577: An Aspect of Spanish Finance in the Early Modern Period." The Historical Journal 25, no. 1 (1982): 1-22.

Lynch, J. "Philip II and the Papacy." Transactions of the Royal Historical Society 11 (1961): 23-42.

Marcos Martín, Alberto. España en los siglos XVI, XVII, y XVIII. Barcelona: Crítica, 2000.

Mitchell, Brian R. British Historical Statistics. Cambridge: Cambridge University Press, 1988.

Mitchener, Kris J., and Marc D. Weidenmier. "Supersanctions and Sovereign Debt Repayment." Journal of International Money and Finance 29, no. 1 (2010): 19-36.

Morineau, Michel. Incroyables gazettes et fabuleux metaux. Cambridge: Cambridge University Press, 1985.

Nadal i Oller, Jordi. La población española: siglos XVI a XX. First corrected and augmented ed. Barcelona: Ariel, 1984.

O'Brien, Patrick K. "Mercantilist Institutions for the Pursuit of Power with Profit: The Management of Britain's National Debt, 1756-1815." In The Fiscal Military State in Eighteenth-Century Europe, edited by C. Storrs, 167-200. Farnham and Burlington: Ashgate, 1997.

Ormrod, W. M., Richard Bonney, and Margaret Bonney. Crises, Revolutions, and Self-Sustained Growth: Essays in European Fiscal History. Stamford: Shaun Tyas, 1999.

Parker, Geoffrey. "Spain, Her Enemies, and the Revolt of the Netherlands, 1559-1648." Past \& Present 49, no. 1 (1970): 71-95.

. The Dutch Revolt. New York: Penguin Books, 1977.

. Spain and the Netherlands, 1559-1659. London: William Collins \& Sons, 1979.

. The Grand Strategy of Philip II. New Haven, CT and London: Yale University Press, 1998.

.The Army of Flanders and the Spanish Roady, 1567-1659: The Logistics of Spanish Victory and Defeat in the Low Countries' War. 2nd edition. New York: Cambridge University Press, 2004.

Reinhart, Carmen M., Kenneth S. Rogoff, and Miguel A. Savastano. "Debt Intolerance." Brookings Papers on Economic Activity 2003, no. 1 (2003): 1-74.

Ruiz Martín, Felipe. "Un expediente financiero entre 1560 y 1575: La hacienda de Felipe II y la Casa de Contratación de Sevilla.” Moneda y Crédito 92 (1965): 358.

. "Las finanzas españolas durante el reinado de Felipe II." Cuadernos de Historia, Anexos de la Revista Hispania 2 (1968): 181-203.

Sargent, Thomas J., and Francois R. Velde. "Macroeconomic Features of the French Revolution.” Journal of Political Economy 103, no. 3 (1995): 474-518.

Sims, Chris. "Comments on 'Debt Intolerance." Brookings Papers on Economic Activity 2003v, no. 1 (2003): 63-74. 
Tenace, Edward Shannon. The Spanish Intervention in Brittany and the Failure of Philip II's Bid for European Hegemony, 1589-1598. Ph.D. diss., University of Illinois, 1997.

. "A Strategy of Reaction: The Armadas of 1596 and 1597 and the Spanish Struggle for European Hegemony." English History Review 118 (2003): 855-82.

t'Hart, Marjolein. "The United Provinces, 1579-1806." In The Rise of the Fiscal State in Europe, c. 1200-1815, edited by R. J. Bonney, 309-26. Oxford: Oxford University Press, 1999.

Thompson, I. A. A. War and Government in Habsburg Spain. London: The Athlone Press-University of London, 1976.

War and Society in Habsburg Spain: Selected Essays. Brookfield: Ashgate Publishing Company, 1992.

. Crown and Cortes: Government, Institutions, and Representation in Early Modern Castile. Aldershot: Variorum, 1993.

. "Castile: Absolutism, Constitutionalism, and Liberty." In Fiscal Crises, Liberty, and Representative Government, 1450-1789. Stanford, CA: Stanford University Press, 1994.

. "Castile: Polity, Fiscality, and Fiscal Crisis." In Fiscal Crises, Liberty, and Representative Government, 1450-1789, edited by P. T. Hoffman and K. Norberg, 140-80. Stanford, CA: Stanford University Press, 1994.

Toboso Sánchez, Pilar. La deuda pública castellana durante el Antiguo Régimen (juros) y su liquidación en el siglo XIX. Madrid: Instituto de Estudios Fiscales, 1987.

Tomz, Michael. Reputation and International Cooperation: Sovereign Debt Across Three Centuries. Princeton, NJ: Princeton University Press, 2007.

Torres López, Manuel, and J. M. Pérez-Prendes. Los Juros (aportación documental para una historia de la deuda pública en España). Fábrica de Moneda y Timbre, 1963.

Tortella, Gabriel, and Francisco Comín. "Fiscal and Monetary Institutions in Spain (1600-1900)." In Transferring Wealth and Power from the Old World to the New: Monetary and Fiscal Institutions in the Seventeenth Through the Nineteenth Centuries, edited by M. D. Bordo and R. Cortés Conde, 140-86. Cambridge: Cambridge University Press, 2001.

Ulloa, Modesto. La hacienda real de Castilla en el reinado de Felipe II. 2 ed. Madrid: Fundación Universitaria Española, Seminario Cisneros, 1977.

Velde, Francois R. “John Law's System.” American Economic Review 97, no. 2 (2007): 276-79.

Weir, David R. "Tontines, Public Finance, and Revolution in France and England, 1688-1789." The Journal of Economic History 49, no. 1 (1989): 95-124.

White, Eugene. "Was There a Solution to the Financial Crisis of the Ancien Regime?" The Journal of Economic History 49, no. 3 (1989): 545-69.

."The French Revolution and the Politics of Government Finance, 1770-1815." The Journal of Economic History 55, no. 2 (1995): 227-55.

"France and the Failure to Modernize Macroeconomic Institutions." In Transfering Wealth and Power from the Old to the New World, edited by M. Bordo and R. Cortes Conde, 59-99. Cambridge: Cambridge University Press, 2001.

Yun Casalilla, Bartolomé. "El Siglo de la Hegemonía Castellana (1450-1590)." In Historia Económica de España, Siglos $X-X X$, edited by F. Comín, M. Hernández and E. Llopis, 51-83. Barcelona: Crítica, 2002.

. Marte contra Minerva: El precio del imperio español, c. 1450-1600. Barcelona: Crítica, 2004. 